\title{
THE USE OF SONGS TO IMPROVE STUDENTS' LISTENING COMPREHENSION ABILITY
}

\author{
Ni Luh Gede Windy Lestary, Si Luh Nyoman Seriadi \\ Institut Hindu Dharma Negeri Denpasar \\ Email: windylestari1199@gmail.com, nyomanseriadi@gmail.com
}

\begin{abstract}
The aim of this journal is to find out the utilization of songs as the technique of teaching listening. Listening is part of four Basic English language skills. It seems like the other skills such as writing, reading, and speaking. These basic skills are divided into receptive skill-listening and reading- and productive skill, speaking and writing. Music and songs are crucial parts of growing and learning. There are many advantages to using songs in the classroom. There are positive and negative views on the utilization of songs in foreign language teaching. Using songs in the learning process especially in the listening lesson it makes the students can improve their listening skill as one of their meaningful strategies to overcome their problem in listening skill. English song can make the students become active in the class, they are interesting, and so they can do a listening task well. However, utilizing songs in the listening process has the challenges, such as; pop songs are not scientific, and inefficient sound systems in schools may cause problems while listening to songs, etc.
\end{abstract}

\section{INTRODUCTION}

Listening is part of four Basic English language skills. It seems like the other skills such as writing, reading, and speaking. These basic skills are divided into receptive skilllistening and reading- and productive skill, speaking and writing. Listening is the activity of paying attention to the speaker and trying to find meaning from something that is heard (Underwood, 1989:1). Listening is the most important language skill and also a part of communication through listening we can share our ideas with other people. According to Brown (2001:24), "Listening is the major component in language learning and teaching because in the classroom learners do more listening than speaking." It means that listening is an important thing in daily life.

Listening is often considered as the most difficult skill. This is because in ELT the teachers tend to prioritize the speaking, reading and writing skills. The students realize that listening comprehension is not easy to learn, they mostly ignore it. This becomes an issue in the world of education, especially for students. Moreover, the conditions worsened with the people assume if someone is able to speak well it is mean that someone can communicate well. In social life, some people believe if they learn English it can be seen from their ability to speak, to write and to read. Actually, someone's language skills it also determined into their listening ability. Wilt (1990) reported that 
people listen to 45 percent of the time they spend communicating. Schwartz (2004:2) states that adults use half from communication activities to listening, while students receive 90\% information in school from listening carefully from the teacher and from other people. However, Adnan (2012:2) states that the learning process of listening skills is not balanced with teaching other language skills such as speaking, reading and writing.

In this case, to improve the quality of education, all of higher education almost requires students to complete their studies both at the Bachelor degree, Master degree, and Doctoral degree levels required to submit a TOEFL certificate with certain minimum score limits accordingly with the policy set by majors and study programs. The three TOEFL test such as; listening comprehension, structure, and written expression and reading comprehension, in part big TOEFL participants say that listening comprehension test is the most difficult test because a lot between students taking TOEFL have to repeat several times until they reach the desired score. This problem is not only a problem by students is approved from non-English majors, but also by the students of the English department.

Some researches that have been conducted by language teaching, researchers have seen that listening skills have their own difficulties when compared to learning other language skills. There are several difficulties in listening to English experienced; 1. Listeners cannot understand what the speakers mean because they cannot control the speed at which people convey the message 2 . Listen to do not have the opportunity to ask the speaker to repeat or clarify that message be delivered. 3. Lack of mastered vocabularies. 4. Error interpreting messages, the meaning of what the speakers mean. Underwood (1990: 15)

Additionally, the facilities of each school become a problem in the learning process. Some schools do not have supporting facilities like a loudspeaker, and earphone. It makes lack of listening comprehension. The learning method is also influenced by the student's comprehension. The students are susceptible to feel bored and not interested in the learning process if the teachers cannot use the accurate method. The students feel bored when the listening class always proposes the same kind of audio. Therefore, one of the methods that the teachers can be used is using a song in teaching listening. Using a song, it will make the students interested in joining the listening class.

According to Lo and Fai $\mathrm{Li}$ (1998:8), learning English through songs are able to change the tedious ambiance in the class, and they can provide a pleasant class environment so that students can develop their lingual skills more easily. Songs are one of the most enchanting and culturally rich resources that can easily be used in language classrooms. Maley (1987) stated songs provide many things that are able to 
strengthen student memories such as sounds, poems, and melodies. It is mean that songs can improve functionality in English Language teaching (ELT). When a student listens and memorizes a song involved in the class, the lyrics are embedded in his long-term memory.

Songs are one kind of listening activity that has broad potential. Music and songs are crucial parts of growing and learning. Some of the significant characteristics of songs are that they are fun and can keep the students excited. There are many advantages to using songs in the classroom. Through using contemporary popular songs, which are already familiar to teenagers, the teacher can meet the challenges of the teenage needs in the classroom. Since songs are highly memorable and motivating the students. The most important feature of songs is repetition. Songs are contained the language patterns, and also develop listening skills, pronunciation, and rhythm, and provide a fun atmosphere. In addition, songs are very beneficial types of activities. It can be used at any stage of a lesson and there are many ways to incorporate them into a lesson. Sometimes, songs are used just as gap fillers and warm-ups, sometimes as the main part of a lesson, but sometimes they are there to provide a fun atmosphere.

\section{DISCUSSION}

\subsection{The Concept of Listening}

There a lot of listening definitions in resources book or internet. Howatt and Dakin (1974) state that listening is the capability to identify and understand what others are saying. It is a process to implicate understanding the speaker's accent or pronunciation, the speaker's grammar and vocabulary, and comprehension of meaning. The term of listening is used in language teaching to refer to a complex process that allows us to understand spoken language. This theory explains that listening is not only recognizing the sounds but also getting the meaning of the word. Additionally, the students also must realize the function of the sentence when it is applied in real-life communication (Carter, 2001: 7). Listening is a receptive skill. People obtain more language rather than produce it. Mukmiatun (2009), states that listening is an imperceptible mental process, making it difficult to describe. Listeners must distinguish between sounds, understand vocabulary and grammatical structures, and also construe this within the immediate as well as the larger socio-cultural context of the utterance. According to Nunan (1970), listening is a kind of capability to identify and understand what other people are talking about. Additionally, listening is also one of the fundamental language skills.

Traditionally, people disregard the role of listening, while overemphasizing the role of reading and writing in learning (Qiu, 2006; Cook, 2001; Rost, 2005). Listening is one of the indispensable abilities in the language. As a kind of input, listening is the foundation of speaking 
and writing. If a student does not receive effective listening input, he or she may not perform well in writing and speaking since the two output abilities are more difficult. Listening is important because listening helps students lay the foundations of speaking and writing. Through listening, students can acquire feasible pronunciation and learn many useful words, phrases, and sentences.

In real-life communication, listening to itself is different from daily listening. It means that the listening activities that are provided in the classroom will accommodate the real-life listening outside the classroom. Therefore, there is so much attention in the listening process as a base for students in a real-life situation. In order to render students with the training of listening that will prepare them in outside classroom listening. The teacher should give them such creative activities. Then, students can translate real-life classroom listening activities to communicate in the real-life listening situation inappropriate word and sentence.

Based on the definition above it can be concluded listening is a process hearing (sounding) weather from a newspaper, radio, or television. The listener must acquire and catch the main idea from the speaker and also what is most important in the listening process are good hearing and concentration. Listening skill needed in mastering English fluently. Besides, listening is one of the important aspects of mastering English has to be passed by the learners. Listening is the most important part in the learning process because listening is a foundation of speaking and writing.

\subsection{Teaching Listening}

Teaching is directing and facilitating learning, and language learning depends on listening. Listening provides the aural input that serves as the basis for language acquisition and enables learners to interact in spoken communication. The effective language teachers show students how they can adjust their listening behavior to deal with a variety of situations, types of input, and listening purposes. They help students develop a set of listening strategies and match appropriate strategies for each listening situation. Nunan (2003) defines listening as an active, meaningful process of making sense of what we hear. Contrary to the common belief that listening is a passive skill and it is usually categorized as a receptive skill; listening is actually a very active skill. When someone listens to something, he does not only obtain information but also reacts to the information by relating or contradicting the new information with the existed or prior information.

Listening is a meaning development activity and divisible listening into three types based on the purpose. The first is listening to repeat; in which students hold listening activities to be able to reiterate the words listened during the practice, the pressure of this type of listening on appropriate 
pronunciation. The second type is listening to understand; in this type of listening to the aim is to improve and practice students' comprehension. The typical strategy used in this type of listening is by giving a task-based listening where the students are given a listening material and asked to answer to complete a task based on the information given in the listening material. The third type of listening is listening to communicate; this listening activity is aimed to repair students' communicative competence and their ability to communicate fluently and meaningfully. This is done through the integration of all the language skills, and developing the skill of anticipating questions, understanding questions, note-taking, as well as pronunciation practices, (Diaz-Rico, 2004: 145-154).

\subsection{The Principles of Teaching Listening}

Listening strategies are techniques or activities that contribute directly to comprehension. Listening strategies can be classified by how the listener processes the input. There are some principles that must be considered when a teacher wants to teach the listening skill, Nunan (2003) proposed the principles as follows:

\section{1) Expose Students with Different Ways of Information Processing System}

There are two information processing system namely the bottom-up and the top-down processing. The bottom-up processing starts with the component's parts of a language such as words, grammar, and etc. On the contrary, the top down processing starts with the student's backdrop knowledge either in the form of the content schema (general information based on prior learning and life experience) or textual schema. Combining these two approaches is the most effective way to help students' learning English specifically in Listening, through a pre-listening brainstorming. The top-down and bottom-up process will work together, resulting in a more integrated attempt of information processing. Buck (1995) maintains that the pre-listening activities aimed at two things, which are to provide a context for interpretation and to activate the background knowledge which will help interpretation.

\section{2) Expose Students to Different Type of Listening.}

Exposing students to different types of listening will help students in focusing the attention to the listening materials based on the purpose of the listening. Nunan (2003: 30-31) explained two types of listening the first is the specific listening, where students have to listen to a material and then try to locate specific information within the text. The second type of listening is the global listening is the type of listening where students try to find out more general information from a material, such as the sequence of events, the main idea, and other global information. 


\section{3) Teach a Variety of Tasks}

Setting up the task of listening activities can be as the tough thing as choosing the material. The listening tasks activities should be considered the students' condition. Seeing most of the listening tasks it is not supposed demanding too much production. For example, a beginner hears a story and asked to write a summary of the story; the task could be difficult simply because the student does not have the ability to write a summary, yet. Tasks that require too much production cannot be done or cannot be done in real time, and should the student come up with the wrong answer the teacher will be having a hard time trying to know whether the students do not understand the listening or simply fail to express their understanding.

\section{4) Always Consider the Authenticity and Difficulty of The Material}

When facing the difficult materials of listening need to be considered with the speed of speech. Since every speaker has different speech rate and decreasing the speech rate of listening material is of course not a solution, because it will hamper the material authenticity. A possible solution is by creating pauses every now and then, either digitally through computer manipulation of the material or manually (by pressing the "pause" button on a tape recorder or other media player). Through this manipulation, the teacher can use a single material for a range of difficulties by giving appropriate pauses.

\subsection{Using Songs as Media of Learning}

Saricoban (2000) claims in-class environment amuses students, can make them feel enjoy and get rid of the uncomfortable atmosphere while learning a lingual structure through a song. Additionally, the positive atmosphere and relaxing mood brought by songs make it easier to resolve the problem in the class. Especially, certain students' emotional cases like anxiety, lack of selfconfidence and feeling of being threatened, and influencing learning processes positively or facilitating it by stimulating the student emotionally (Kramsch, 1993). Songs are also motivating the students as they provide a good atmosphere. The students are encouraged to actively involved in the learning process by making use of their musical knowledge. In this case, songs are an effective way to help students to expand confidence for language learning (Şahin, 2008). Orlova (2003) claims these are some of the strength for working in class with songs:

a. Practicing the rhythm, stress and the intonation patterns of the English language.

b. Teaching vocabulary, especially in the vocabulary reinforcement stage.

c. Teaching grammar, teachers while investigating the use of the tenses especially favor songs.

d. Teaching speaking. For this purpose, songs and mainly 
their lyrics are employed as a stimulus for class discussions.

e. Teaching listening. Music can be helpful for comprehension.

f. Developing writing skills. It means a song can be used in a type of ways; for example, speculation as to what could happen to the characters in the future, writing a letter to the main character, etc.

\subsection{The Criteria for Selecting Songs in Language Teaching}

Songs are essential sources to be utilized during language teaching. Besides positive effects, there are of course difficulties encountered while using songs in language teaching. Terhune (1997: 8) states there are the difficulties thing when using songs as a media of learning:

a. Pop songs are not scientific.

b. Each student has a different way of learning; some students may have difficulty in studying through music.

c. Inefficient sound systems in schools may cause problems while listening to songs.

d. The types of music favored by students may not be matching with each other.

e. Songs that are not grammatical or those involving complicated sentence structures may confuse students.

f. Some songs, there may be disgraceful parts that cannot be explained to students.

g. Repetition of a limited number of words it makes the song to seem boring or ineffective.
Some teachers do not have adequate knowledge about music and teacher-training programs do not involve anything regarding how to utilize music in language teaching aimed by Jensen (2000). The weakness of using songs is the lack of the capability to slow down the speed of the song when a grammatically difficult part is playing, or to fasten it when there is the repetition of certain parts (Miller, 2002). In the other hand, some teachers think that they cannot sing a song. However, using a song in the class for this aim does not necessitate any expertise in this field. Griffe (1992) lists four elements to be considered while choosing a song to be used in the class as follows:
a. Classroom environment (number, age, and interests of students; lesson hours)
b. Teacher (teacher's age, interest in music and aim to use the song in the class
c. Classroom facilities (flexibility in the lesson plan, classroom equipment)
d. Music (lesson plan and equipment such as the volume, sources of music, board, etc.)

Griffe (1992) recommends using short and slow songs for students on the beginner level. Crosswords, drawing or picture showing exercises can be conducted with such songs. For the students with a higher language level, long and fast songs that tell a story should be used. The song to be chosen should have a clear sound and it should be 
comprehensible; there should not be too many instruments played with a high volume in the song.

\subsection{Activities through the Utilization of Songs}

The Activities that using songs in foreign language classes can be classified into three, such as; prelistening, listening and post-listening activities. The teacher should conscientiously think about what a student will do before, while and after listening. There are some recommendations regarding these activities' stages and what kind of activities a teacher can use in these stages:

\section{Pre-Listening}

Davenellos (1999) states, "The aim of this stage is to prepare students to a topic grammatically, educationally and psychologically". The teachers necessarily explain the topic, the keyword, and the structures before playing a song. In this stage, to activate students' background information, it could be suitable to ask the students to guess the theme of a song, to brainstorm about it.

Pre-listening activities it makes students to consciously with the aim of listening to the song and catch the meaning of the song while listening. This stage is meant to train the learners to predict text based on their knowledge such as language, topic, or background of knowledge.

\section{Listening}

Listening activities are directly related to the text and students are expected to carry out these activities in the course of listening. In this process of listening and by the guidance of the teacher, students control their comprehension skills and focus on listening to the text.

This stage is to help the students understand the texts. However, they are not expected to understand every word. In this case, the students who participate actively in the listening experience are more likely to construct clear, accurate meaning as they interpret the speaker's verbal cues. During the listening experience, students verify and revise their predictions. They make interpretations and judgments based on what they know, assessing what more they need to know

\section{Post-Listening}

According to Davenellos (1999), various activities for assessing the whole process of listening can be conducted in this stage. It consists of follow-up activities for developing speaking and writing skills. The aim of this stage is to help the students connect with what they heard with their own ideas, experience and encourage interpretive and critical listening and reflective thinking. There are some examples of exercise in post-listening: Using notes made while listening to write a summary, reading a related text, doing a roleplay, writing on the same theme, and practicing pronunciation.

Basically, teachers need to prepare those three stages of the lesson plan. There is pre-listening, listening, and post-listening. Those 
activities activate the students to achieve the aim of learning and make the learning process undergo smoothly. If the teachers can apply the three stages, it is mean the learning process of listening will be running successfully. That means both of the teacher and students will achieve the goals of learning.

\subsection{Empirical Review}

Additionally, some researchers doing research about using songs in the listening process. There are prior researches about the effect of using a song as the media of teaching listening. First, Dadang Solihat and Prita Lusiana Utami (2014) from the Department of English Education, University of Kuningan, Indonesia with the journal "Improving Students' Listening Skill by Using English Songs". They conducted it can be seen during the writers teaching at SMPN in Kuningan, the lack of capability of the students in listening skill. The aims of this research were to investigate the effectiveness of using English songs to improve students listening. The subject of the research is the 62 students in the eighth grade of SMPN 1 Lebakwangi, Kabupaten Lebakwangi. The author used a quasiexperimental method. The results showed that the students' progress in mastering listening skills during the activity can be seen from the pair. There are two groups as the investigated group in this research. In this research, the improvement of students' listening skill by using an English song can be seen from the result of the students' score in the test.
English song can make the students become active in the class; they are interested. So, they can do the listening task well. In conclusion, the improvement of students' listening skill by using English song was different after they got the treatment, it was seen from students' score in the pre-test to the post-test that analyzed by paired test. The treatment of English is effective to improve students' listening skill in the eighth grade of junior high school.

Secondly, Tri Listiyaningsih (2017) conducted in the journal "The Influence of Listening English Song to Improve Listening Skill in Listening Class" from IAIN Surakarta. Base on her journal showed that listening English song can improve the listening skill because the song can be media to improve listening skill. When someone learns about the English language, they should comprehend in listening skill because listening is one of skill that must comprehend in learning the English language. Listening to English song can add the vocabularies, improve pronunciation, and can make comprehend in listening skill and there is a way to improve listening skill. Vocabularies can be obtained because people will usually to listen to the English word and it can add new vocabularies. Improve pronunciation can obtain because when listening to English song, the singer usually is a native speaker of English and they will pronounce English well. So that people can use the English song to improve their ability. 
The last previous research is conducted by Apin Hidayat (2013) entitled "The Use of Songs in Teaching Students' Listening Ability". $\mathrm{He}$ is from the English Education Study Program of the Indonesia University of Education. This study was aimed at first investigating whether or not the use of songs significantly improves students' listening skill. Second, the difficulties faced by the students in listening comprehension were also investigated. This quasi-experimental research involved two classes of students of a public junior high school in Sumedang. The media of teaching and learning process, in this case, songs, not only help the teacher to teach listening but also provide an interesting way for the students to achieve the learning goals. The media is one of the effective ways of making the students understand well the delivered lesson. The content of the songs may become one of the influential factors which may determine the improvement of the students' listening ability. The use of songs also should consider students' need so that it will help students to learn and achieve the learning objective. The teacher ability in selecting teaching material will also influence the use of songs in improving the students' listening ability.

\section{CONCLUSION}

The use of technology needs to apply in the classroom as much as possible. Utilizing the technology for language teaching is of great importance, and the tendency to integrate technology with lesson content grows each day. Accordingly, utilizing songs through technology in a lesson environment attract attention. There are positive and negative views on the utilization of songs in foreign language teaching. Using songs in the learning process especially in the listening lesson it makes the pleasant atmosphere in the class and make the teachers explain the topic or the material easily. The students also can improve their listening skill as one of their meaningful strategies to overcome their problem in listening skill. English song can make the students become active in the class, they are interesting, and so they can do a listening task well. However, utilizing songs in the listening process has the challenges, such as; pop songs are not scientific, inefficient sound systems in schools may cause problems while listening to songs, the types of music favored by students may not be matching with each other, etc. Finally, we should bear in mind that every day our profession is more demanding and we have to be ready to face the challenges that come up, finding solutions or different alternatives.

\section{REFERENCES}

Adnan, Aryuliva. (2012). Pengajaran Menyimak Bahasa Inggris: Masalah dan Solusinya. Available at http://ejournal.unp.ac.id/index.p hp/linguadidaktika/article/view $\angle 2549$

Asmawati, Andi. (2017). Analyzing Students' Difficulties toward 
Listening Comprehension. ETERNAL Volume 3, Number 2, December 2017. Available at http://journal.uinalauddin.ac.id/index.php/Eterna 1/article/view/4592

Atmowardoyo, Haryanto. (2018). The Use of Digital Storytelling in Teaching Listening Comprehension: An Experimental Study on the Eighth Grade Students of SMP Negeri 4 Parepare. ELT Worldwide Volume 5 Number 1 (2018). Available at https://ojs.unm.ac.id/ELT/article $\measuredangle$ view/5763/pdf 15

Brown, Steven. (2006). Teaching Listening. Cambridge University Press.

Davies, Paul et. al. (2000). Success in English Teaching. Oxford: Oxford University Press.

Hedge, Tricia. (2000). Teaching and Learning in the Language Classroom. Oxford: Oxford University Press.

Hidayat, Apin. (2013). The Use of Songs in Teaching Students' Listening Ability. Journal of English and Education 2013, 1(1), 21-29. Available at http://ejournal.upi.edu/index.ph $\mathrm{p} / \mathrm{L}-\mathrm{E} / \mathrm{article} / \mathrm{view} / 322 / 211$

Izzah, Lidiyatul. (2014). Implementing Song in Teaching Listening Comprehension at Muhammadiyah University of Jakarta. MORPH Vol. 1 No.2 1/2October 2014 I Page 1-13. Available at https://www.researchgate.net/p ublication/324278611 Implemen ting Song

in Teaching_Listening_Compre hension at Muhammadiyah U niversity of Jakarta.

Listiyaningsih, Tri. (2017). The Influence of Listening English Song to Improve Listening Skill in Listening Class. Academia, Vol. 1 No. 1, Januari- Juni 2017 ISSN: 2579-9703 (P) | ISSN: 2579-9711 (E). Available at http://ejournal.iainsurakarta.ac.i d/index.php/academica/ article/download/601/177.

Mahardika, Wijaya. I.G.N.A. (2018). Developing English Listening Material for The Seventh Year Students of Junior High School. JOELE Vol. 1, Issue 1 March 2018. Available at http://ejournal.ihdn.ac.id/index. php/JOELE/article/view/714.

Mukminatun, Siti. (2009). Empowering the Students through Listening Diaries to Motivate Students to Improve their Listening Ability. Yogyakarta State University.

Nunan, David. 2003. Practical English Language Teaching. New York.

Rehage, Kenneth J. (1976). The Psychology of Teaching Methods. Chicago: The University of Chichago Press.

Ronald Carter-David Nunan. (2001). The Cambridge Guide to Teaching English to Speakers of Other Language. Cambridge: Cambridge University Press.

Saricoban, Arif. (2000). Songs, Verse, and Games for Teaching Grammar. Vol. VI, No. 10, October 2000 . at 
http://iteslj.org/Techniques/Saric oban-Songs.html.

Solihat, Dadang, \& Utami, Prita. (2014)._Improving Students' Listening Skill by Using English Songs. ERJEE, Vol. 3, Issue 1, December 2014. Available at https://www.academia.edu/2974 1696/IMPROVING STUDENTS LISTENING SKILL BY USIN G ENGLISH SONGS

Xiao, Wang. (2013). The Function of English Songs to Improve Listening to Collage English as A Second Language (ESL) Students. Available at: https://core.ac.uk/download/pdf/ 10597955.pdf 